\title{
Strategy for Improving Self-Efficiency and Organizational Climate in Efforts to Increase Employee Performance of PT. Indo Webhost Kreasi with Employee Engagement as Intervening Variable
}

\author{
Eko Marabinkhak Simbolon ${ }^{1}$, Sukaria Sinulingga ${ }^{2}$, Iskandarini ${ }^{2}$ \\ ${ }^{1,2}$ Master of Management Study Program on Postgraduate School of University of Sumatera Utara. \\ Corresponding Author: Eko Marabinkhak Simbolon
}

DOI: https://doi.org/10.52403/ijrr.20220225

\begin{abstract}
Human resources will process other resources by using technology to achieve organizational goals. The objective of the research is to find out the influence of self-efficacy and organizational climate on employee engagement as intervening variables. The research employs a descriptive causal method with a quantitative approach. The population consists of all 74 employees and the data are analyzed by using a structural equation model with Smart PLS software program. The result of the calculation shows that self-efficacy has positive dan significant influence on employee performance. The result of the calculation shows that, indirectly, self-efficacy has a positive and significant influence on employee performance through employee engagement as the intervening variable can influence self-efficacy and organizational climate on employee performance. The variable of employee engagement has the most dominant influence on employee performance at the original sample of 0.500 .
\end{abstract}

Keywords: self-efficacy, organizational climate, employee engagement, employee performance

\section{BACKGROUND}

The rapid advancement of technology encourages business actors to use internet access in their part of work. In the past, many companies only used the internet to send e-mails, now the need for the internet has become more widespread, such as use for meetings, administrative needs, use of information systems, and so on. The need for internet does not only occur at the head office, even now internet usage has reached branches or units.

On the basis of the increasingly widespread need for internet usage, this has been responded to by the number of internet provider companies or so-called Internet Service Providers (ISPs), both nationally and locally. There are several companies present in this industry, one of which is PT Indo Webhost Kreasi. As a local ISP industry player, PT. Indo Webhost Kreasi is entering a special segment in the ISP industry, where they focus on business to business strategy, or towards corporate business. Several ISPs are playing in retail, or the target users are the public, PT. Indo Webhost Kreasi realizes that there are many players who focus on retail, so they focus on corporate business.

To be able to run a business and develop, companies need workers to develop the company. The workforce processes resources by utilizing technology to achieve company goals. Based on the 2018-2020 evaluation data, it is stated that the service performance of PT. Indo Webhost Kreasi continues to increase every year even though it has not yet reached the standards set by the company. This problem is caused by a lack of awareness from 

increase employee performance of pt. Indo webhost kreasi with employee engagement as intervening variable.

employees of the responsibilities given by the company so that it is often found that employees only work when monitored by the leadership. PT. Indo Webhost Kreasi also realizes that the facilities provided and support from the company for employees such as transportation access for employees who work outside the office are still considered lacking. In addition, according to the management of PT. Indo Webhost Kreasi, the self-efficacy of employees is still lacking on the ability of the employees themselves. This causes frequent tasks to be neglected and service to customers who are still considered unsatisfactory.

Positive management characteristics must be in accordance with employee expectations so that employee engagement is formed, (Timpe, 1992). Employee engagement is the perception that the workforce plays an important role in realizing organizational goals and seeks to improve their performance beyond the targets set by the company. Another opinion was put forward by (Gallup, 2013) where employee engagement itself is the high level of labor engagement so that it contributes more to the company. The work bond involves the workforce both cognitively and emotionally, if these two things are involved it will form a strong relationship so that they have great responsibility for their work, are punctual, and full of enthusiasm when working. Based on the results of interviews with researchers at the management of PT. Indo Webhost Kreasi related to employee engagement issues for 74 active employees from 5 divisions identified several problems as described below:

Table 1. employee engagement employees of PT. Indo Webhost Creations

\begin{tabular}{|c|l|c|c|c|c|}
\hline \multirow{2}{*}{ No. Position } & \multicolumn{3}{|c|}{ Employee Engagement } & \multirow{2}{*}{ Result } \\
\cline { 3 - 5 } & Spirit (\%) & $\begin{array}{c}\text { Dedicate } \\
(\%)\end{array}$ & $\begin{array}{c}\text { Absorption } \\
(\%)\end{array}$ & \\
\hline 1.Human Resources & 40 & 40 & 40 & Not Engaged \\
\hline 2.Information Technology & 40 & 20 & 40 & Not Engaged \\
\hline 3. Engineering & 20 & 40 & 40 & Not Engaged \\
\hline 4. Business Development & 40 & 40 & 20 & Not Engaged \\
\hline 5.Support & 20 & 20 & 20 & Not Engaged \\
\hline
\end{tabular}

Employee engagement level of PT. Indo Webhost Kreasi is still in the not engaged category. This is because there are still many employees think that PT. Indo Webhost Kreasi is only limited to finding work experience and becoming a career stepping stone to a bigger company with the hope of a bigger salary, so employees often find other activities that are not related to the demands of their duties during operating hours. In addition, the management of PT. Indo Webhost Kreasi also realizes that the salary given to employees is still far below the UMK in Medan City, so it is often found that employees are less than optimal at work. The small salary received by employees because the company is still in the start-up category so that the profits received by the company are not comparable to other IT Development companies that have been around for a long time.

Fahmi Ilman (2020) conducted research entitled The Effect of Employee Engagement and Self Efficacy on Employee Performance. The number of samples is 118 people. The data analysis method is descriptive statistical analysis with the help of SPSS program to measure data quality, quantitative analysis, classical assumption test, and hypothesis testing. Based on the results of the employee variable data and efficacy stated constant on the performance of 2,769. The employee regression coefficient is 0.271 , so it can be stated that there is an influence between employee and performance. The efficacy regression coefficient is 0.419 , so it can be stated that there is an influence between efficacy and performance. 

increase employee performance of pt. Indo webhost kreasi with employee engagement as intervening variable.

Richa Chaudhary, Santosh Rangnekar, and Mukesh Kumar Barua (2011) conducted a study entitled HRD Climate and Occupational Self Efficacy as Predictors of Employee Engagement. Number of samples as much as 66 people. The data analysis method is multiple linear regression which is operated through SPSS. Based on the data results, the HRD climate and occupational self-efficacy variables have a simultaneous positive effect on employee engagement with a simultaneous value of 80,046 . Self efficacy has a significant effect partially with an $\mathrm{R}^{2}$ value of 0.709 and a $P$ value below 0.05 .

Alessandri, et al., (2014) stated that self-efficacy affects employee performance to achieve success at work. Lack of selfefficacy in one's own abilities is doomed to failure. So it needs to be understood that self-efficacy is able to encourage employees to develop their performance (Ilman, 2020).
Employee performance can be explained by organizational climate, efficacy, and employee. The better the company climate and efficacy, the better employee engagement will be, thus providing good performance (Nugrahadi, A., et al., 2019). So it is necessary to understand that performance is influenced by internal and external factors, internal factors are influenced by the person concerned and external factors are influenced by organizational climate (Fajriah, $\mathrm{N}$ and Marcham Darokah, 2016). With employee engagement, the workforce is aware of a strong bond to work so that the company's targets are achieved (Ardi, 2017). Workers who have ties to the company will work more so that it helps organizations gain cognitive advantage and achieve organizational goals (Garg, N and Brij Sharma, 2015).

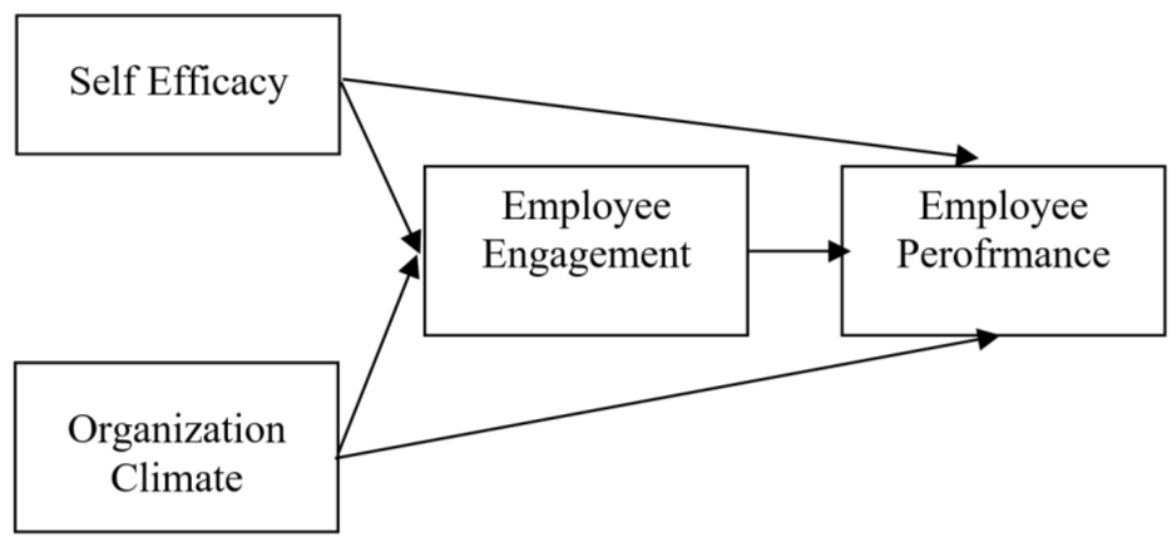

Figure 1. Conceptual Framework

\section{Hypotheses}

H1 : There is a significant effect of SelfEfficacy (X1) on Employee Engagement (Z).

$\mathrm{H} 2$ : There is a significant influence of Organizational Climate (X2) on Employee Engagement ( $\mathrm{Z})$.

H3 : There is a significant effect of SelfEfficacy (X1) on Employee Performance (Y).

$\mathrm{H} 4$ : There is a significant influence of Organizational Climate (X2) on Employee Performance (Y).
H5 : There is a significant effect of Employee Engagement (Z) on Employee Performance (Y).

H6 : There is a significant effect of Self Efficacy (X1) on Employee Performance (Y) through Employee Engagement (Z).

$\mathrm{H} 7$ : There is a significant influence of Organizational Climate (X2) on Employee Performance (Y) through Employee Engagement ( $\mathrm{Z})$.

\section{RESEARCH METHOD}

This type of research is causal descriptive with quantitative analysis. 
Causal research aims to analyze cause-andeffect relationships by analyzing the effects that occur and the factors that cause these effects. the population in this study were all employees of PT. Indo Webhost Kreasi, totaling 74 people. The samples of this study were all members of the population as samples, namely employees of PT. Indo Webhost Kreasi as many as 74 people. Data collection through interviews, communication with the leadership and all employees of PT. Indo Webhost Kreasi. Questionnaire, by submitting a written statement to all employees of PT. Indo Webhost Kreasi regarding the problem being researched. In this study, the questionnaire measurement scale used was the Likert scale. The data analysis technique used in this research is PLS analysis using the Smart PLS 3.0 application. PLS analysis is a variance-based structural equation analysis to test the measurement model and test the structural model.

\section{RESULT AND DISCUSS Structural model of inner model}

Table 2. R Square

\begin{tabular}{|l|c|}
\hline \multicolumn{1}{|c|}{ Variabel } & $\mathrm{R}^{2}$ \\
\hline Employee Engagement $(\mathrm{Z})$ & 0,630 \\
\hline Employee Performance $(\mathrm{Y})$ & 0,617 \\
\hline
\end{tabular}

a. Employee performance is influenced by self-efficacy, organizational climate, and employee engagement by $61.7 \%$ and the rest is influenced by other variables.

b. Employee engagement is influenced by self-efficacy and organizational climate by $63 \%$ and the rest is influenced by other variables.

\section{Hypothesis Testing}

Table 3. bootstrapping value test

\begin{tabular}{|l|r|r|r|r|r|}
\hline \multicolumn{1}{|c|}{ Hypotheses } & \multicolumn{1}{|c|}{$\begin{array}{c}\text { Original } \\
\text { Sample }\end{array}$} & \multicolumn{1}{|c|}{ Averages } & \multicolumn{1}{|c|}{$\begin{array}{c}\text { Standard } \\
\text { Deviation }\end{array}$} & $\begin{array}{c}\text { T } \\
\text { Statistic }\end{array}$ & \multicolumn{1}{c|}{$\begin{array}{c}\text { V- } \\
\text { Values }\end{array}$} \\
\hline $\begin{array}{l}\text { Self Efficacy (X1) } \rightarrow \\
\text { Employee Engagement(Z) }\end{array}$ & 0,480 & 0,485 & 0,136 & 3,542 & 0,000 \\
\hline $\begin{array}{l}\text { Organization Climate (X2) } \rightarrow \\
\text { Employee Engagement (Z) }\end{array}$ & 0,369 & 0,372 & 0,127 & 2,917 & 0,004 \\
\hline $\begin{array}{l}\text { Self Efficacy (X1) } \rightarrow \text { Employee } \\
\text { Performance (Y) }\end{array}$ & 0,457 & 0,455 & 0,101 & 4,549 & 0,000 \\
\hline $\begin{array}{l}\text { Organization Climate (X2) } \rightarrow \\
\text { Employee Performance(Y) }\end{array}$ & 0,317 & 0,330 & 0,130 & 2,447 & 0,015 \\
\hline $\begin{array}{l}\text { Employee Engagement (Z) } \\
\rightarrow \text { Employee Performance(Y) }\end{array}$ & 0,500 & 0,483 & 0,161 & 3,100 & 0,002 \\
\hline $\begin{array}{l}\text { Self Efficacy (X1) } \rightarrow \\
\text { Employee Engagement (Z) } \\
\rightarrow \text { Employee Performance (Y) }\end{array}$ & 0,240 & 0,237 & 0,103 & 2,322 & 0,021 \\
\hline $\begin{array}{l}\text { Organization Climate (X2) } \rightarrow \\
\text { Employee Engagement (Z) }\end{array} \rightarrow$ Employee Performance (Y) & 0,185 & 0,181 & 0,086 & 2,146 & 0,032 \\
\hline
\end{tabular}

1. Positive and relevant results were found between Self-Efficacy (X1) and Employee Engagement (Z). The test results state that the original sample value is 0.480 , the t-statistic value is 3.542 which is greater than 1.96 with a $\mathrm{P}$-Values value of 0.000 less than 0.050 , then the first hypothesis is accepted.

2. Positive and relevant results were found between Organizational Climate (X2) and Employee Engagement (Z). The test results state that the original sample value is 0.369 , the t-statistic value is 2.917, which is greater than 1.96 and the $\mathrm{P}$-Values is 0.004 less than 0.050 , so the second hypothesis is accepted.

3. Positive and relevant results were found between Self-Efficacy (X1) on Employee Performance (Y). The test results state that the original sample value is 0.457 , the t-statistic value is 4.549 which is greater than 1.96 with a P-Values of 0.000 less than 0.050 , so the third hypothesis is accepted. 
4. Positive and relevant results were found between Organizational Climate (X2) on Employee Performance (Y). The test results state that the original sample value is 0.317 , the t-statistic value is 2,447 which is greater than 1.96 with a P-Value of 0.015 less than 0.050 , so the fourth hypothesis is accepted.

5. Positive and relevant results were found between Employee Engagement $(\mathrm{Z})$ on Employee Performance (Y). The test results stated that the original sample value was 0.500 , the t-statistic value of 3.100 was greater than 1.96 with a PValues value of 0.002 less than 0.050 , so the fifth hypothesis was accepted.

6. Positive and relevant results were found between Self-Efficacy (X1) on Employee Performance (Y) through Employee Engagement (Z). The test results state that the original sample value is 0.240 , the t-statistic value is 2.322 which is greater than 1.96 with a P-Values of 0.021 less than 0.050 , so the sixth hypothesis is accepted.

7. Positive and relevant results were found between Organizational Climate (X2) on Employee Performance (Y) through Employee Engagement (Z). The test results state that the original sample value is 0.185 , the $t$-statistic value is 2.146 which is greater than 1.96 with a $\mathrm{P}$-Values of 0.032 which is smaller than 0.050 , so the seventh hypothesis is accepted.

\section{CONCLUSION}

1. Self-efficacy is positive and relevant to Employee Engagement at PT. Indo Webhost Kreasi, this is due to the lack of ability of the employees of PT. Indo Webhost Kreasi in completing difficult tasks, employee readiness in facing difficulties is still in the low category, tenacity and tenacity of employees are still in the low category so they try to separate themselves from their work.

2. Organizational climate is positive and relevant to Employee Engagement at PT. Indo Webhost Kreasi. Most of the employees of PT. Indo Webhost Kreasi is in the category of assessment of a negative organizational climate. This refers to a negative assessment of support and appreciation perceived by employees.

3. Self-efficacy is positive and relevant to employee performance at PT. Indo Webhost Kreasi. When employees are unable to complete a difficult task, the employee will delay the task so that the task will pile up and cause the performance achievement target to not be met.

4. Organizational climate is positive and relevant to employee performance at PT. Indo Webhost Kreasi. Clear job descriptions, support, and awards are some of the factors that can provide an overview and consideration in determining the climate of an organization.

5. Employee Engagement is positive and relevant to Employee Performance at PT. Indo Webhost Kreasi. It is often found that employees lack concentration and are less serious in their work, resulting in low organizational performance.

6. Self-efficacy is positive and relevant to Employee Performance through Employee Engagement at PT. Indo Webhost Kreasi. Lack of ability of employees of PT. Indo Webhost Kreasi in completing difficult tasks and the readiness of employees to face difficulties is still in the low category, so that the company's productivity is always below the target because task completion is often late.

7. Organizational climate is positive and relevant to Employee Performance through Employee Engagement at PT. Indo Webhost Kreasi. Overall employees of PT. Indo Webhost Kreasi is in the category of assessment of a negative organizational climate.

Acknowledgement: None 


\section{Conflict of Interest: None}

\section{Source of Funding: None}

\section{REFERENCES}

1. Alessandri, G., Laura, B., Wilmar, B. S., Gian, V. C., \& Chiara, C. 2014. From Positive Orientation to Job Performance: The Role of Work Engagement and SelfEfficacy Beliefs. Journal Happines Study,Vol. 16, Hal. 767-788.

2. Anitha. 2014. Determinants of Employee Engagement and Their Impact on Employee Performance. International Journal of Productivity and Performance Management, Vol. 63, No. 3, Hal. 308-323.

3. Ardi, V. T. P. 2017. Pengaruh Self Efficacy Terhadap Employee Engagement Dan Kinerja Karyawan. Dipublish Sarjana Skripsi. Universitas Brawijaya (Indonesia).

4. Ariarni, N dan Tri. W. A. 2017. Pengaruh Organizational Support Terhadap Kinerja Karyawan Dengan Employee Engagement Sebagai Variabel Intervening. Universitas Brawijaya (Indonesia).

5. Bandura, A. 1997. Self Efficacy: The Exercise of a Control. New York: W. H. Freeman and Company.

6. Bakker, A., and Demerouti, E. 2014. The Job Demand Resources Model : State of the art. Journal of Managerial Psycology, Vol. 22, No. 3, Hal. 309- 328.

7. Bernardin, H. J. 2003. Human Resource Management: An Experiential Approach. New York: McGraw-Hill Education.

8. Bonner, S. E., and Sprinkle, G. B. 2002. The Effect of Monetary Incentive on Effort and Task Performance: Theories, Evidence, and Framework of Research. Journal of Organization and Society, Vol. 27, Hal. 303-345.

9. Chaudhary, R., Santosh, R., \& Mukesh, K. B. 2011. HRD Climate and Occupational Self - Efficacy as Predictors of Employee Engagement. Journal of Management Studies, Vol. 1, No. 3, Hal. 16-28.

10. Cooper, W. W., Lawrence, M. S., \& Kaoru, T. 2006. Introduction to Data Envelopment Analysis and Its Uses: With DEA-Solver Software and References, Ninth Edition. United States of America: Springer.

11. Fajriah, N., dan Marcham, D. 2016. Pengaruh Efikasi Diri Dan Persepsi Iklim Organisasi Terhadap Kinerja Karyawan
Dengan Employee Engagement Sebagai Variabel Mediator Pada Karyawan BMT BIF Yogyakarta. Jurnal Humanitas, Vol. 13, No. 1, Hal. 37-49.

12. Federman, Brad. 2009. Employee Engagement: A Roadmap for Creating Profits, Optimizing Performance, and Increasing Loyalty. San Francisco: JosseyBass A Wiley Imprint.

13. Gallup. 2013. State of the Global Workplace: Employee Engagement Insight for Business Leaders Wordwide. New Jersey: Gallup, Inc.

14. Garg, N and Brij, S. 2015. The Mediating Role of Employee Engagement in the Relationship between High Performance Work Practice and Job Performance. Journal of Management NMIMS, Vol. 28, Hal. 13-15.

15. Gibson, dkk., 2010. Organisasi, Perilaku, Struktur, Proses. Jakarta: Bina Rupa Aksara.

16. Hair, J., Black, W., Babin, B. J., \& Anderson, R. 2010. Multivariate Data Analysis, Seventh Edition. United States: Pearson.

17. Hakanen, J. J., and Peteers, M. 2015. How Do Work Engagement, Workaholism, and The Work to Family Interface Affect Each Other? A Seven Years Follow Up Study. Journal of Occupational and Environmental Medicine, Vol. 57, No. 6, Hal. 601-609.

18. Handoko, T. H. 2008. Manajemen Personalia dan Sumber Daya Manusia, Edisi Kedua. Yogyakarta: BPFE.

19. Hestya, W., dan Setiorini. 2012. Hubungan Kerja Shift Terhadap Kelelahan Perawat Di Instalasi Rawat Inap RSUD Dr. Sayidman Magetan. Jurnal Kesehatan Lingkungan, Vol. 3, No. 5, Hal. 95-120.

20. Holloway, J. B. 2012. Leadership Behavior and Organizational Climate: An Empirical Study in a Non - profit Organizational. Journal of Emerging Leadership Journeys, Vol. 5, Hal. 9-35.

21. Ilman, F. 2020. Pengaruh Employee Engagement And Self Efficacy Terhadap Kinerja Karyawan, Publish Sarjana Skripsi, UIN Jakarta (Indonesia).

22. Kawiana, I. G. P., Luh, K. C. D., Luh, K. B. M., \& Ida, B. R. S. 2018. The Influence of Organizational Culture, Employee Satisfaction, Personality, and Organizational Commitment towards Employee Performance. International Research 
Eko Marabinkhak Simbolon et.al. Strategy for improving self-efficiency and organizational climate in efforts to increase employee performance of pt. Indo webhost kreasi with employee engagement as intervening variable.

Journal of Management, IT \& Social Sciences, Vol. 5, No. 3, Hal. 35-45.

23. Nugrahadi, A., Aziz, F., \& Heru, S. W. 2019. The Effect of Organizational Climate, Work Life Quality, and Individual Characteristics on Employee Performance With Employee Association as Variables Between Gramedia Pandanaran Semarang. Jurnal of Management, Vol. 1, Hal. 2-9.

24. Patterson. 2009. Organizational Change Management: Getting From Here to There. New York: Knowledge Peak.

25. Robbins, S. P., dan Judge, T. A. 2006. Perilaku Organisasi, Edisi Kesepuluh. Jakarta: PT. Indeks Kelompok Gramedia.

26. Santrock, J. W., and Rollo, D. 2017. Psicologia Dello Sviluppo. New York: McGraw-Hill Education.

27. Schaufeli, W. B., Salanova, M., GonzalezRoma, V., \& Bakker, A. B. 2002. The Measurement of Engagement and Burnout: A Confirmative Analytic Approach. Journal of Cross-Cultural Psychology, Vol. 3, Hal. 71-92.
28. Sinambela, L. P. 2012. Kinerja Pegawai Teori Pengukuran dan Implikasi. Yogyakarta: Graha Ilmu.

29. Sinulingga, S. 2017. Metode Penelitian. Medan: USU Press.

30. Stringer, R. 2002. Leadership and Organizational Climate. New Jersey: Prentice Hall.

31. Sugiyono. 2017. Statistika Untuk Penelitian. Bandung: Alfabeta.

32. Timpe, A. D. 1992. The Art and Science of Business Management Performance. Mumbai: Jaico Publishing House.

How to cite this article: Eko Marabinkhak Simbolon, Sukaria Sinulingga, Iskandarini et.al. Strategy for improving self-efficiency and organizational climate in efforts to increase employee performance of PT. Indo Webhost Kreasi with employee engagement as intervening variable. International Journal of Research and Review. 2022; 9(2): 174-180. DOI: https:// doi.org/10.52403/ijrr.20220225 